\title{
The Integration of Modern Information Technology and College English Teaching to Improve the Effectiveness of English Teaching
}

\author{
Dan Li \\ English Department \\ Liaoning Institute of Science and Technology \\ Benxi, China
}

\begin{abstract}
The introduction of multimedia assisted teaching into the English classroom has undoubtedly injected new vitality into the reform of English subject teaching. The expression form of both sound and image is perfect, and the activity and simulations are both appropriate. However, in the application of multimedia in English teaching, there are many problems. In this paper, teachers' application of multimedia, utilization and development of media resources are discussed. Proposed ways to solve such problems by using modern technology of informatization combined with traditional teaching methods are presented here. The main emphasis placed on the method is to incorporate modern information technology into teaching design. Compared with the traditional teaching methods, the new teaching mode can bring a new life to the college English class. And effective strategies to deal with such problems are also illustrated with stress on the main body of students, rich cultural background, situational establishment and diverse forms of homework. The abundant teaching content strengthened by modern teaching means, thus brings the English classroom person brand-new realm.
\end{abstract}

Keywords—modern means; multimedia; innovation; education informatization; cultivate

\section{INTRODUCTION}

With the development of information technology, information dissemination has been developing at an unprecedented speed and breadth, which has brought about profound changes in all aspects of school education. In order to achieve classroom teaching innovation with modern information technology, improve the effect of English teaching under the background of "Internet + ", and invert the traditional classroom teaching structure, teachers need to integrate modern information technology with the use of multimedia advantages , actively introduce micro-lessons, lessons for network classroom resources, and realize the construction of a "flip" classes. With the support of network resources, more flexible and effective learning can be attained, it is very important both for students' future development and for the construction of classroom teaching.

As early as 2004, "college English course teaching requirements" issued by the higher education department of the Ministry of Education clearly stipulated that "advanced information technology should be extensively used to promote computer-based network teaching" in college English course setting and teaching mode."Colleges and universities should make full use of multimedia and network technology and adopt a new teaching model to improve the original single classroom teaching model based on teachers."In the context of "Internet $+"$, which is the important embodiment of educational informatization, it is far from enough to rely solely on courseware and micro-lectures made by teachers in our school to legalize the construction of English flipped classroom. The application of modern information technology in college English teaching can not only make up for the deficiency of traditional teaching and effectively improve classroom efficiency, but also conform to the development trend of college English teaching reform.

Modern information technology refers to the use of computer, network, radio and television and other hardware equipment and software tools and scientific methods, including the acquisition, processing, storage, transmission and use of all kinds of information on the text and audio images. Modern information technology application of college English teaching mainly refers to the advanced teaching idea, the multimedia computer technology and network communication technology under the guidance of teaching theory as a tool in the form of a combination with effective college English teaching. It has become an organic part of English course content in order to improve the students' ability to collect information, use and process information, reading ability and writing ability, cultivate students' autonomous learning ability and cooperation spirit, to complete the task of English teaching effectively. [1]

\section{Problems Existing in Traditional College ENGLISH TEACHING}

\section{A. Single classroom teaching methods}

In many Chinese colleges and universities, English teaching is still using the teaching mode which is centered on teachers, teaching materials and classrooms. But in the process of language teaching, it is limited by the above three media to explain. Such a teaching mode cannot make full use of the senses of the students, the perceptual knowledge and intuitive impression. Neglecting the student's main body status, students are in a passive position such a classroom teaching. In the long term, students will lose enthusiasm to actively participate in the whole class activities and are not willing to think actively. In addition, limited to the traditional college English teaching of 
language forms such as phonetics, grammar and vocabulary teaching, the English teaching methods emphasize knowledge and neglect language application ability, without considering the individual difference and subjective initiative of students. It won't create circumstances to mobilize students' learning environment and it's not good to improve the students' ability of practical application. In the condition of passive learning students easy to produce fatigue. Despite of hard work, teachers have little effect on improving efficiency. [2]

\section{B. Many coursewares have the following defects}

In the courseware making, teachers are one-sidedly in pursuit of visual effect with too colorful forms, ignoring the quality of courseware content. It is easy for students to look at the dazzling screen and ignore the understanding of the key points and difficult points of teaching, which will distract students from learning, dilute the theme and cause the situation of putting the cart before the cart. On the other hand, courseware production is too simple with only the blackboard into a computer projection. Between the teaching mode and traditional teaching, there is no qualitative change. It is difficult to achieve an effective combination of multimedia and foreign language teaching to improve teaching efficiency.

\section{Lack of cultural background knowledge support, language communication environment is not real}

Language comes from culture, and the construction of language always has certain cultural connotations. It contains the cultural background of the nation, as well as the nation's view on life, way of life and way of thinking. Without such a background, the language also has no life. In order to successfully communicate in English, it is not enough to master only the language knowledge such as pronunciation, grammar and vocabulary. We should learn how they express their thoughts in that language which reflects their actions and habits Therefore, the English class divorced from the cultural background is empty and powerless, which will make students feel indifferent in language learning, thus losing their enthusiasm and interest in learning. And in traditional teaching due to the limitations of time and space, it is difficult to create real communication scene for learners. It is formed over a long period of time is given priority to with teacher's teaching, mainly on reading comprehension teaching idea and mode. Many college students who passed English CET 4 or CET 6 exams, but they dare not communicate with foreigners. Even in some graduation thesis English abstract also needs help from others. This is mainly because the students only know the knowledge of the books through mechanically repeated memory, mechanically copy. They do not know the appropriate environment in which the language should be put e, resulting in poor language application ability.

\section{Teaching design ability and technology ability of the application of multimedia are not good}

Teaching design is a systematic method to solve problems in teaching, so that teachers can reasonably and effectively arrange various factors in the teaching process and ensure the smooth realization of teaching objectives. Due to the influence of traditional teaching ideas, many teachers believe that the key to teaching is teachers' teaching and students' learning, and teaching design is nothing more than teachers preparing lessons before class. Therefore, in the use of multimedia for English teaching, the overall layout and design of teaching is not enough. The teaching thinking is confused, so the teaching process is either completely depending on the teaching courseware or experience and situation teaching, with blindness and randomness, lack of initiative and creativity. Multimedia teaching requires teachers to spend a lot of time and energy to find materials and make courseware. However, many foreign language teachers find it difficult to apply the skilled application of multimedia technology in foreign language teaching practice due to the limitations of the computer application level, and often due to improper operation, technical failure, the paralysis which makes teaching in a passive situation. That seriously affects the teaching process, and to some extent, restricts the development of multimedia English teaching.

\section{The ApPlication Strategy OF MODERN INFORMATION TECHNOLOGY IN COLLEGE ENGLISH TEACHING}

\section{A. Students are the main body}

As the latest theoretical basis of modern education technology constructivism believes that knowledge is not taught by teachers, but learners make full use of various learning resources (including written materials, audio-visual materials, multimedia courseware software tools and various teaching information obtained from the Item et, etc.), in certain situations, the social and cultural background, with the help of other people, including teachers and learning partners) help, by meaningful construction. With the assistance of modern information technology, college English teaching is characterized by the emphasis on students' initiative, enthusiasm and creativity in the learning process. For example, multimedia network technology breaks through the limitation of space and time in teaching, and enables students to learn knowledge in various ways. Students can consult and visit the curriculum plan, and choose the teaching content of different media on the Internet or in the courseware according to their language level, cognitive style, personality characteristics and learning interests. During the learning process, students can communicate directly with teachers and other students through one-to-one communication or network, or communicate indirectly through E-mail, telex and other means. In this way, multimedia teaching has taken care of the individual differences of students, satisfied the individual needs of learners, highlighted the autonomy of students in learning, and fundamentally changed the central position of teachers in traditional teaching. Students have become the leading role in class, while teachers are only the guide and organizer. Of course, new teaching methods can help improve the efficiency of foreign language teaching, but they can never replace the role of teachers. Teachers' teaching activities are often carried out among students, which is two-way communication between teachers and students full of emotion. The teacher stands in front of the student, uses the vivid language, the image analogy, the appropriate body language and the exchanges, to create the classroom atmosphere which is also the English language teaching essential link. Therefore, attention should be paid to the combination of traditional teaching methods and multimedia teaching. Teachers should timely adjust the 
classroom atmosphere so as to avoid students tired of learning. [3]

\section{B. Rich cultural background}

As a basic content of language teaching, cultural background knowledge is necessary and important in language learning and communication. In this teaching link, the teacher can use the rich network resources to vividly show the native English speaking country customs in the form of multimedia courseware with sound, image, effectively changing the traditional teaching imagination and confusion which are difficult to understand. At the same time, that can fully stimulate students' learning enthusiasm, strengthen their perceptual knowledge, change from being passive into active, and produce good teaching results. In addition, the use of rich and colorful information on the Internet can be taken as a guide for appropriate information in classroom teaching, which can give students a fresh feeling, stimulate students' interest in learning and desire for knowledge, by which teachers build a platform for the smooth development of classroom teaching and play a role in expanding and deepening knowledge.

\section{Situational language}

Constructivism emphasizes the role of learning environment in learning, and believes that "situation", "cooperation", "conversation" and "meaning construction" are the four elements of learning environment. It is important for college foreign language teaching to create a real and lively teaching environment so that both teaching and learning can be in a positive state and classroom teaching can be contextualized. The acquisition of communicative competence and skills in English requires a lot of repeated language practice. Therefore, it is very necessary to create real language situations for English teaching. In English teaching practice, micro-class is an important resource for the construction of the flipped classroom. In the teaching process, teachers can incorporate video fragments, teaching design, practice tests, student feedback, teacher comments and other auxiliary teaching resources into micro-class, and guide students to realize independent learning by using micro-class which is short, flexible and easy to operate. Teachers can use multimedia and network technology to make the teaching content sound and emotion, through the description of language, text, image demonstration, animation simulation, music rendering and the use of color for students to create a realistic environment, so that students personally understand the relevant knowledge, fully stimulate their learning interest and enthusiasm. Through virtual classroom discussion, a variety of games, role play and other ways.

\section{Homework presents diversity}

As the tool of information processing and knowledge building, teachers can use information technology help students to realize the purpose of the internalization of a lot of knowledge. In the process of internalization, communication and exchanges can be carried out to help the students extract large amounts of information, reorganize the information, process and recycle, cultivate students' access to information, analyzing information, the ability of processing information, the use of information. Teachers can use E-mail, BBS and other network communication tools to assign homework to students. They can pass some learning materials to students through the network in a timely manner, and students put forward online answers to the questions, submit homework through E-mail, ask the teacher, and strengthen the communication between teachers and students. Teachers can also organize students through QQ groups, blogs and other forms of thematic discussion, answer questions and exchange ideas. However, it is necessary to pay attention to the problem that teachers should give timely feedback on students' homework, discussion and communication, otherwise, these links will become a mere formality. In addition, after class, students can also find English learning partners through the Internet. Through online communication, students' English expression ability can be improved. According to their own learning situation and time schedule, students can self-control of their own learning process. [4]

\section{THE SignificANCE OF INTEgRATING MOdeRn INFORMATION TECHNOLOGY TO THE INNOVATION OF ENGLISH TEACHING METHODS}

In English teaching practice, integrating modern information technology to create a dynamic and intelligent teaching environment is not only the need for innovative teaching methods but also the choice of exploring new teaching reform paths.

A. It is conducive to enhance students' participation in English teaching when students learning enthusiasm is not high and the problem of low interest in learning

In the information age, it is difficult for teachers to introduce students' curiosity and interest by using the old traditional model. Only by adopting innovative technologies and creative methods can students be mobilized to participate in teaching activities actively. Information technology provides strong technical support for teaching.

\section{B. It is conducive to build an equal and harmonious teacher- student relationship}

Teachers should re-recognize the dominant position in information-based teaching practice, promote the change of roles of teachers and students according to the needs of the flipped classroom, and give full play to the auxiliary role of teaching to escort students' independent learning. In the multimedia classroom of information technology, students become the main body of learning, and teachers act as guide to help students learn English independently.

\section{It is conducive to utilize the rich classroom teaching resources}

In traditional blackboard + textbook classroom teaching model classroom resources are less, but in the era of the rapid development of Internet technology, teachers should use Internet technology to enrich the classroom content, make the curriculum more diverse. In the classroom, teachers can also use network technology for situational teaching, improve students' ability of listening, speaking, and reading and writing, mobilize the classroom atmosphere, broaden students' knowledge and improve their oral English ability. 


\section{CONCLUSION}

Integrate modern information technology to optimize the leading-in link of teaching and arouse interest in English learning. The introduction of teaching is the beginning of teaching practice. Integrating modern information technology to design and optimize the introduction of teaching can not only enable students to have a preliminary knowledge of English. Moreover, it can lay a solid foundation on the psychological level and improve students' enthusiasm to participate in classroom practice. In the introduction of English teaching, teachers can start from the following aspects:

The integration of information technology and English teaching has enriched the content of textbooks, optimized the teaching process, enhanced students' interest in learning, aroused their thirst for knowledge and cultivated their innovative spirit. At the same time, the integration of information technology and English teaching by modern English teaching has provided a broad activity in heaven and earth, led to the deepening of teaching reform, makes education more profound changes take place in the teaching field, strategies of teaching methods, teaching means of modernization and informatization. The teaching of simple operation has gradually become a reality. [5]

\section{ACKNOWLEDGMENT}

"Research and practice of web-based three-dimensional college English teaching" Liaoning provincial education science "12th five-year plan 2015 annual project 2015(JG15DB192)

\section{REFERENCES}

[1] Wu Xiaoping "Discussion on Innovative Development of Rural ECommerce in Anhui” [J]. Business Era, 2010 (3)

[2] Zhong Yanguang, Guo Hong. Basic Information Technology. Xi'an: Xidian University Press

[3] Zhang Guoying. Computer-Aided Foreign Language Teaching and Research. Shanghai: Shanghai Foreign Language Education Press, 1994.

[4] Xu Yanhong. Using Multimedia Network Classroom to Promote the Reform of College English Teaching Model. Theory of Chinese Extramural Education, 2007

[5] Zhang Kaiyu, Influence of Multimedia and Internet on English Teaching [J], Gansu Cultural Education, 2005(5) 